\title{
Antitumor effects of the novel quinazolinone MJ-33: Inhibition of metastasis through the MAPK, AKT, NF-кB and AP-1 signaling pathways in DU145 human prostate cancer cells
}

\author{
MANN-JEN HOUR $^{1 *}$, SHIH-CHANG TSAI ${ }^{3 *}$, HSI-CHIN WU ${ }^{7,2}$, MENG-WEI LIN ${ }^{3}$, JING-GUNG CHUNG $^{3}$, \\ JIN-BIN WU ${ }^{1,5,6}$, JO-HUA CHIANG ${ }^{8}$, MINORU TSUZUKI ${ }^{9,6}$ and JAI-SING YANG ${ }^{2,4}$ \\ Schools of ${ }^{1}$ Pharmacy, and ${ }^{2}$ Medicine, China Medical University, Taichung 404; Departments of ${ }^{3}$ Biological \\ Science and Technology, and ${ }^{4}$ Pharmacology, China Medical University, Taichung 404; ${ }^{5}$ Graduate Institute \\ of Pharmaceutical Chemistry, China Medical University, Taichung 404; ${ }^{6}$ Tsuzuki Institute for Traditional \\ Medicine, China Medical University, Taichung 404; ${ }^{7}$ Department of Urology, China Medical University \\ Hospital, Taichung 404; ${ }^{8}$ Department of Life Sciences, National Chung Hsing University, Taichung 402, Taiwan, \\ R.O.C.; ${ }^{9}$ Department of Biochemistry, Nihon Pharmaceutical University, Saitama 362-0806, Japan
}

Received April 24, 2012; Accepted June 20, 2012

DOI: $10.3892 /$ ijo.2012.1560

\begin{abstract}
Quinazolinone compounds have been shown to have antitumor activity in many human cancer cell lines. In the present study, we investigated the anti-metastatic activity of MJ-33 (2-(3-ethoxyphenyl)-6-pyrrolidinylquinazolinone), a novel quinazolinone derivate, and the signaling pathway of MJ-33 in human prostate cells. MJ-33 exhibited a growth inhibitory effect on DU145, LNCaP and PC-3 cells by MTT assay. DU145 cells showed greater sensitivity to the growth inhibition of MJ-33 than that of LNCaP and PC-3 cells. MJ-33 also had an inhibitory effect on the invasion, migration and adhesion of DU145 cells using Boyden chamber transwell assays, wound-healing and adhesion assay. In addition, MJ-33 inhibited cell metastasis through the reduction of matrix metalloproteinase-2 (MMP-2), matrix metalloproteinase-9 (MMP-9) and urokinase-type plasminogen activator (u-PA) enzyme activities and protein levels by gelatin zymography assay and western blot analysis, respectively. MJ-33 reduced the protein levels of p-JNK, p-p38, p-ERK, p-AKT and nuclear NF- $\mathrm{BB}$ (p65), c-fos and c-Jun protein levels by western blotting. Using electrophoretic mobility-shift assay (EMSA), we demonstrated that MJ-33 blocked the activation of transcription factor AP-1 (activator protein-1) and NF- $\mathrm{kB}$, which led to the inhibition of MMP-2 and MMP-9 expression. Collectively, our data showed
\end{abstract}

Correspondence to: Dr Jai-Sing Yang, Department of Pharmacology, China Medical University, No. 91 Hsueh-Shih Road, Taichung 40402, Taiwan, R.O.C.

E-mail: jaising@mail.cmu.edu.tw

*Contributed equally

Key words: quinazolinone MJ-33, invasion, migration and adhesion, MAPK, AKT, NF- $\kappa$ B and AP-1 signaling pathways, human prostate cancer DU145 cells that MJ-33 decreased protein levels of MAPKs (mitogenactivated protein kinases), AKT, AP-1 and NF- $\mathrm{KB}$, resulting in the inhibition of matrix metalloproteinases. Downregulation of MMP-2 and MMP-9 reduces the invasion, migration and adhesion activities of DU145 cells. MJ-33 may be a promising agent against prostate cancer metastasis.

\section{Introduction}

Prostate cancer is one of the leading causes of mortality in men (1) and has a highly variable natural history. Prostate cancer may be present as an indolent and silent entity throughout a man's life and then grow rapidly following metastasis to the lymph nodes and bones with a median life expectancy of 24-36 months (2). Therefore, prostate cancer is largely asymptomatic until metastases are present and it is largely a disease of the elderly. It is reasonable to propose that agents which inhibit metastasis could have great therapeutic efficacy.

Quinazoline derivatives are known for multiple effects, such as anti-malarial, anti-inflammatory (3), anti-bacterial, and antitumor activities (4). In recent years, we have designed and synthesized a series of quinazoline derivatives as new anti-mitotic agents $(5,6)$. Our previous study showed that synthesized 6-pyrrolidinyl-4-quinazolinone derivative MJ-29 inhibited tubulin polymerization through binding to $\beta$-tubulin at the colchicine-binding site and acted as an anti-mitotic agent (5). Furthermore, we demonstrated that 6-fluoro(3-fluorophenyl)-4-(3-methoxyanilino)quinazoline (LJJ-10) exhibits anti-metastatic effects in human osteosarcoma U-2 OS cells through targeting the insulin-like growth factor-I receptor (IGF-IR) (6). In the present study, we investigated the effects of MJ-33 on invasion, migration and adhesion in DU145 human prostate cancer cells. MJ-33 inhibited migration and invasion through downregulation of matrix metalloproteinases (MMPs) and urokinase-type plasminogen activator (u-PA) through the AP-1 and NF- $\mathrm{B}$ signaling pathways. 


\section{Materials and methods}

Chemicals and reagents. MJ-33 was designed and synthesized by Mann-Jen Hour and Sheng-Chu Kuo (China Medical University, Taichung, Taiwan) (Fig. 1). Dimethylsulfoxide (DMSO), potassium phosphates, propidium iodide (PI) and triton X-100 were obtained from Sigma-Aldrich (St. Louis, MO, USA). RPMI-1640 medium, fetal bovine serum (FBS), L-glutamine, penicillin-streptomycin, and trypsin-EDTA were obtained from Gibco-BRL (Invitrogen, Grand Island, NY, USA). Antibodies against phospho-AKT, phospho-JNK, phospho-ERK and phospho-p38 were purchased from Cell Signaling Technology Inc. (Danvers, MA, USA). Antibodies against AKT, JNK, ERK, p38, $\beta$-actin, MMP-2, MMP-9, $\mathrm{u}-\mathrm{PA}, \mathrm{NF}-\kappa \mathrm{B}$ (p65), c-fos, c-Jun and all peroxidase-conjugated secondary antibodies were purchased from Santa Cruz Biotechnology, Inc. (Santa Cruz, CA, USA). Antibody against $\beta$-actin was purchased from Sigma-Aldrich.

Cell culture. The DU145, LNCaP and PC-3 human prostate cancer cell lines were obtained from the Food Industry Research and Development Institute (Hsinchu, Taiwan). All cells were individually plated onto $75 \mathrm{~cm}^{2}$ tissue culture flasks with $90 \%$ RPMI-1640 medium. Cell medium with $2 \mathrm{mM}$ L-glutamine was adjusted to contain $1.5 \mu \mathrm{g} / \mathrm{ml}$ sodium bicarbonate, supplemented with $10 \% \mathrm{FBS}, 100 \mathrm{Units} / \mathrm{ml}$ penicillin and $100 \mu \mathrm{g} / \mathrm{ml}$ streptomycin. The cells were grown at $37^{\circ} \mathrm{C}$ under a humidified $5 \% \mathrm{CO}_{2}$ atmosphere.

Cell viability. Approximately $5 \times 10^{4}$ cells/well of DU145, LNCaP and PC-3 cells were individually grown in 96-well plates for $24 \mathrm{~h}$ before different concentrations of MJ-33 were added $(0,50,100,250$ and $500 \mathrm{nM})$. Cells were incubated at $37^{\circ} \mathrm{C}, 5 \% \mathrm{CO}_{2}$ and $95 \%$ air for 24 and $48 \mathrm{~h}$. Following treatment, the supernatant was discarded before a $100 \mu$ l solution of MTT $(500 \mu \mathrm{g} / \mathrm{ml})$ was added to each well for $4 \mathrm{~h}$ at $37^{\circ} \mathrm{C}$. After incubation, the violet formazan crystal produced from MTT was solubilized by the addition of $100 \mu \mathrm{l}$ of DMSO. The absorbance of the dissolved formazan grained within the cells was measured at $570 \mathrm{~nm}$ by a microplate reader as previously described (6).

Cell invasion assay. Twenty-four-well Transwell inserts with $8 \mu \mathrm{m}$ porosity polycarbonate filters (Millipore, Billerica, MA, USA) were pre-conted with $30 \mu \mathrm{g}$ Engelbreth-HolmSwarm sarcoma tumor extract (EHS Matrigel Basement Membrane Matrix) at room temperature for $1 \mathrm{~h}$ and then formed a genuine reconstituted basement membrane. DU145 cells $\left(1 \times 10^{4}\right.$ cells/0.5 ml RPMI-1640) were placed onto the upper compartment and incubated with MJ-33 (0, 50, 100 and $200 \mathrm{nM})$. The plates were then incubated at $37^{\circ} \mathrm{C}$ for $24 \mathrm{~h}$ in a humidified atmosphere with $95 \%$ air and $5 \% \mathrm{CO}_{2}$. The cells were fixed with $4 \%$ formaldehyde in PBS and stained with $2 \%$ crystal violet. Cells on the upper surface of the filter were removed by wiping with a cotton swab, and cells that penetrated through the matrigel to the lower surface of the filter were counted under a light microscope at $\mathrm{x} 200$. Each treatment was assayed in duplicate, and three independent experiments were carried out as previously described $(7,8)$.

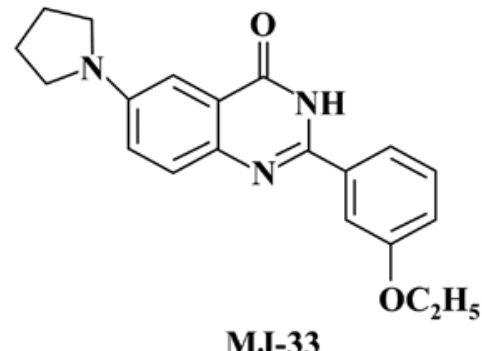

2-(3-Ethoxyphenyl)-6-pyrrolidinylquinazolinone

Figure 1. The chemical structure of MJ-33 (2-(3-ethoxyphenyl)-6-pyrrolidinylquinazolinone).

Cell migration assay. Approximately $5 \times 10^{4}$ DU145 cells $/ \mathrm{ml}$ were plated in 6-well plates for $24 \mathrm{~h}$ and then the cells in individual wells were wounded by scratching with a pipette tip and incubated with or without FBS free RPMI-1640 medium and treated with or without MJ-33 (0, 50, 100 and $200 \mathrm{nM})$ for $24 \mathrm{~h}$. The cells were photographed under phase-contrast microscopy (x100) and calculated. Each treatment was assayed in duplicate, and three independent experiments were carried out as previously described $(7,8)$.

Cell adhesion assay. The cell-matrix adhesion assay was used to determine cell adhesion. DU145 cells were plated on a 24-well plate after treatment with or without MJ-33 (0, 50, 100 and $200 \mathrm{nM}$ ) for $24 \mathrm{~h}$. Then the individual cells were removed to a plate coated with $150 \mu \mathrm{l}$ of type I collagen $(10 \mu \mathrm{g} / \mathrm{ml})$ and cultured for $30 \mathrm{~min}$. Non-adherent cells were removed by PBS washing, and adherent cells were fixed in ethanol. After staining with $0.1 \%$ crystal violet, fixed cells were lysed in $0.2 \%$ Triton-100 and measured at $550 \mathrm{~nm}$ by a microplate reader. Each treatment was assayed in duplicate, and three independent experiments were done as previously described $(7,8)$.

Zymography assay. To determine the activity of MMP-2, MMP-9 and u-PA, quantitative gelatin zymography was performed with standard methods. Briefly, cells $\left(1 \times 10^{7}\right.$ cells $\left./ \mathrm{ml}\right)$ were treated with MJ-33 (0, 50, 100 and $200 \mathrm{nM})$ for $24 \mathrm{~h}$. Cells were harvested and separated by dilution in zymography sample buffer. Samples were electrophoresed in an $8 \%$ SDS-polyacrylamide gel containing $1 \%$ gelatin, and incubated in renaturing buffer (2.5\% Triton X-100). Electrophoresis was performed at $110 \mathrm{~V}$ for $3 \mathrm{~h}$. The gel was incubated with development buffer (50 mM Tris, $\mathrm{pH} 7.5,200 \mathrm{mM} \mathrm{NaCl}$, $5 \mathrm{mM} \mathrm{CaCl}_{2}, 1 \mu \mathrm{M} \mathrm{ZnCl}_{2}, 0.02 \% \mathrm{Brij}_{-35)}$ at $37^{\circ} \mathrm{C}$ for $18 \mathrm{~h}$, and stained with $0.5 \%$ Coomassie blue G-250 for $3 \mathrm{~h}$. The gels were digitized using a scanning digitizing system and analyzed using NIH image software. The u-PA activity was performed by casein-plasminogen zymography. Briefly, $2 \%$ casein and $20 \mu \mathrm{g} / \mathrm{ml}$ plasminogen were added to an $8 \%$ SDS-PAGE gel. Samples with a total protein of approximately $30 \mu \mathrm{g}$ were then loaded onto the gels. The u-PA activity of cells treated with or without MJ-33 was measured as described for the gelatin zymography assay $(7,8)$.

Preparation of whole-cell lysate and nuclear extract. Approximately $1 \times 10^{7}$ cells were treated with MJ-33 (0, 50, 
100 and $200 \mathrm{nM}$ ) for 6 or $24 \mathrm{~h}$. The cells were harvested and whole-cell lysed with iced-cold RIPA buffer (1\% NP-40, $50 \mathrm{mM}$ Tris-base, $0.1 \%$ SDS, $0.5 \%$ deoxycholic acid, $150 \mathrm{mM}$ $\mathrm{NaCl}, \mathrm{pH} 7.5)$, and then phenylmethanesulfonyl fluoride $(10 \mathrm{mg} / \mathrm{ml})$, leupeptin $(17 \mathrm{mg} / \mathrm{ml})$, and sodium orthovanadate $(10 \mathrm{mg} / \mathrm{ml})$ were added $(9,10)$ and vortexed for $30 \mathrm{~min}$ on ice. The samples were centrifuged at $12,000 \mathrm{~g}$ for $10 \mathrm{~min}$. Nuclear extracts were prepared from MJ-33-treated DU145 cells using the NE-PER Nuclear and Cytoplasmic Extraction kit (Pierce, Rockford, IL, USA). Each nuclear pellet was collected and was then re-suspended in nuclear extract buffer $(1.5 \mathrm{mM} \mathrm{MgCl}$, $10 \mathrm{mM}$ HEPES, pH 7.9, $0.1 \mathrm{mM}$ EDTA, $0.5 \mathrm{mM}$ dithiothreitol, $0.5 \mathrm{mM}$ phenylmethanesulfonyl fluoride, $25 \%$ glycerol, and $420 \mathrm{mM} \mathrm{NaCl}$ ). The nuclear suspension was incubated for $20 \mathrm{~min}$ on ice then centrifuged at $14,000 \mathrm{~g}$ for $5 \mathrm{~min}$. The supernatant (the soluble nuclear fraction) was saved and the remaining pellet was solubilized by sonication in PBS. The protein content in each sample was determined by using Bio-Rad protein assay reagent using bovine serum albumin as the standard. Nuclear extracts were prepared for NF- $\mathrm{B}, \mathrm{c}-\mathrm{fos}$, and c-Jun western determination (11).

Western blotting. Cells were harvested and the total and nuclear proteins were collected as described above. Protein abundance of MMP-2, MMP-9 and u-PA, p-JNK, p-ERK, p-p38, p-AKT, JNK, ERK, p38, AKT, NF-кB (p65), c-fos and c-Jun were determined by sodium dodecyl sulfate-polyacrylamide gel electrophoresis (SDS-PAGE) and western blotting as previously described $(5,12-15)$.

Electrophoretic Mobility Shift Assay (EMSA). Approximately $1 \times 10^{7}$ cells were treated with MJ-33 (0, 100 and $\left.200 \mathrm{nM}\right)$ for $6 \mathrm{~h}$. Nuclear extracts were prepared from MJ-33-treated DU145 cells using the NE-PER Nuclear and Cytoplasmic Extraction kit (Pierce). The protein concentrations were determined and Biotin end-labeled oligonucleotide sequences 5'-BiotinGATCCAGGGGACTTTCCCTAGC-3' corresponded to the consensus site of NF- $\kappa \mathrm{B}$ and Biotin end-labeled oligonucleotide sequences 5'-Biotin-CGCTTGATGACTCAGCCGGAA-3' corresponded to the consensus site of AP-1. Nuclear extract proteins $(5 \mu \mathrm{g})$ were used for EMSA with a LightShift Chemiluminescent EMSA Kit according to the manufacturer's protocol. Biotin end-labeled duplex DNA was incubated with a nuclear extract or purified factor and electrophoresed on a $6 \%$ polyacrylamide native gel. For competition experiments, a 100-fold excess of unlabeled double stranded oligonucleotide was added to the reaction. The DNA was then rapidly transferred to a positive nylon membrane, UV cross-linked, probed with streptavidin-HRP conjugate and incubated with the substrate of the ECL kit $(16,17)$.

Statistical analysis. Student's t-test was used to analyze differences between treated and control groups. ${ }^{*} \mathrm{p}<0.05$ was considered to indicate a statistically significant difference.

\section{Results}

MJ-33 induces growth inhibition effects on human prostate cancer cell lines. We determined the growth inhibition effects of MJ-33 on the human prostate cancer cell lines DU145,
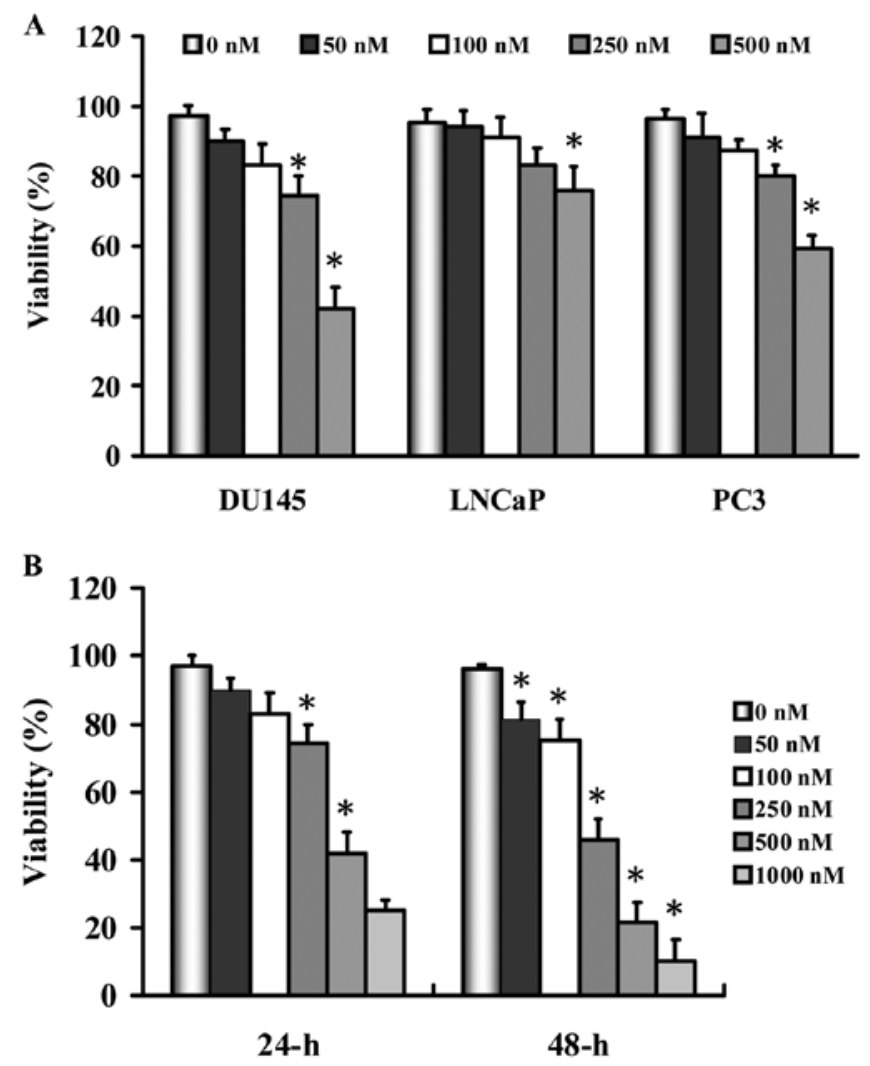

Figure 2. MJ-33 induces cytotoxic effects in human prostate cancer cell lines (A) Cells (DU145, LNCaP and PC-3) were treated with MJ-33 (0, 50, 100, 250 and $500 \mathrm{nM}$ ) for $24 \mathrm{~h}$ then viable cells were determined by MTT assay. (B) DU145 cells were treated with MJ-33 $(0,50,100,250,500$ and $1000 \mathrm{nM})$ for 24 and $48 \mathrm{~h}$ and the viable cells were determined by MTT assay, as described in Materials and methods. Each point is the mean \pm SD of three experiments. ${ }^{*} \mathrm{p}<0.05$ indicates a significant difference compared to the control.

LNCaP and PC-3. As shown in Fig. 2, MJ-33 inhibited the cell growth of the three cell lines in a concentration-dependent manner. DU145 cells were more sensitive by MJ-33 than that of the other two cell lines. We therefore investigated whether or not MJ-33 could induce a concentration- and time-dependent growth inhibition effect on DU145 cells. As seen in Fig. 2B, MJ-33 decreased the percentage of viable DU145 cells in a concentration- and time-dependent manner, but we selected less than $200 \mathrm{nM}$ of MJ-33 for further works in this study.

MJ-33 inhibits invasion, migration and adhesion of DU145 cells. The effects of MJ-33 on cell invasion were examined using Matrigel-coated Transwell assay in DU145 cells. As shown in Fig. 3A, MJ-33 (50-200 nM) significantly inhibited cell invasion in a concentration-dependent manner; the percentage of inhibition ratio was $15-70 \%$. The inhibition of DU145 cell migration by MJ-33 was examined using the wound-healing assay. As shown in Fig. 3B, MJ-33 (50-200 nM) significantly inhibited cell migration in a concentrationdependent manner; the percentage of inhibition ratio was $30-75 \%$. The inhibition of DU145 cell adhesion by MJ-33 was examined by using cell adhesion assay. As shown in Fig. 3C, MJ-33 (50-200 nM) significantly inhibited cell adhesion in a concentration-dependent manner; the percentage of inhibition ratio was $10-45 \%$. MJ-33 did not affect cell viability at 

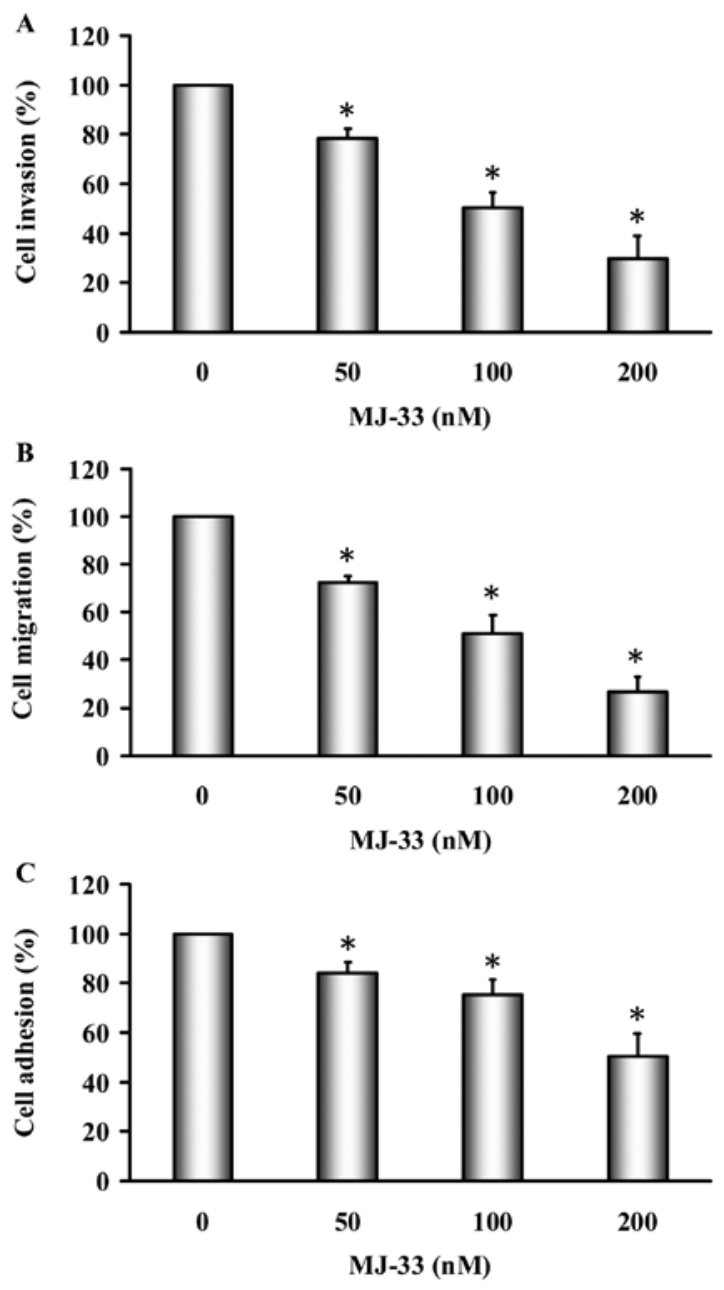

Figure 3. MJ-33 inhibited cell invasion, cell migration, and adhesion activities of DU145 cells in vitro. (A) Cells that penetrated through the matrigel to the lower surface of the filter were stained with crystal violet and counted under a light microscope at $\times 200$. (B) Cells were plated in 6-well plates, were then wounded by scratching with a pipette tip and incubated with FBS free RPMI-1640 medium with or without MJ-33 for 24 and $48 \mathrm{~h}$. The cells were calculated as the percentage of inhibition of migration. (C) Cells were seeded on a 24-well plate and coated, and were then cultured for $30 \mathrm{~min}$. Non-adherent cells were removed and adherent cells were fixed in ethanol to examine the percentage of adhesion cells as described in Materials and methods. " $p<0.05$ indicates a significant difference compared to the control.

50-200 $\mathrm{nM}$ of 24-h treatment. On the other hand, the $\mathrm{EC}_{50}$ is 458.32 $\pm 6.96 \mathrm{nM}$ for $24 \mathrm{~h}$ in MJ-33-treated DU145 cells. Our results demonstrated that $\mathrm{MJ}-33$ inhibited the effects of cell invasion, migration and adhesion in DU145 cells. Also, the inhibitory effects of MJ-33 on invasion, migration and adhesion are independent of cellular cytotoxicity.

MJ-33 inhibits MMP-2, MMP-9 and $u-P A$ enzyme activities of DU145 cells. We investigated the mechanisms of cell invasive phenotype by determining the involvement of MMP-2, MMP-9 and u-PA. DU145 cells were treated with MJ-33 (0, 50, 100 and $200 \mathrm{nM}$ ) for $24 \mathrm{~h}$. The MMP-2, MMP-9 and u-PA activities were determined by gelatin or casein zymography. As shown in Fig. 4, we found that MJ-33 inhibited individual activity of MMP-2, MMP-9 (Fig. 4A) and u-PA (Fig. 4B). Reductions in activity are consistent with decreases in protein abundance of MMP-2, MMP-9 and u-PA, as shown in Fig. 5A.
A
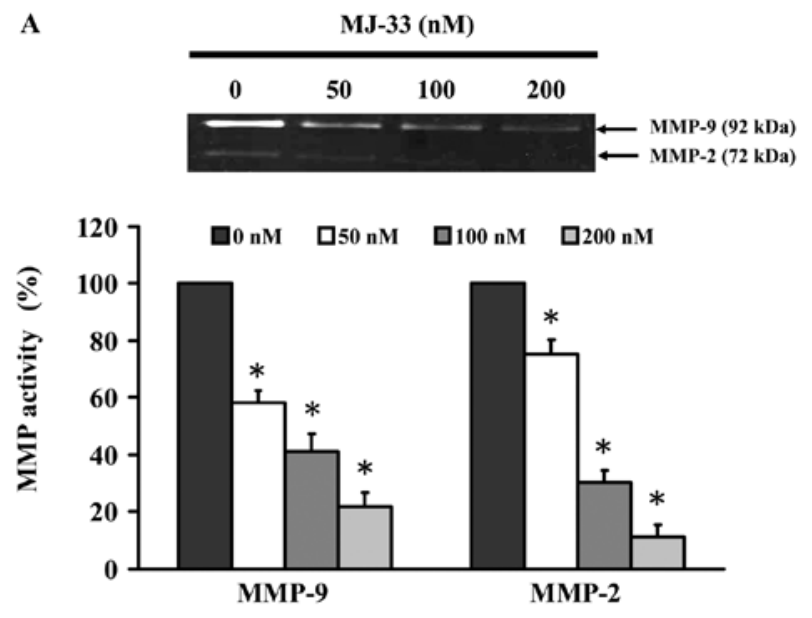

B
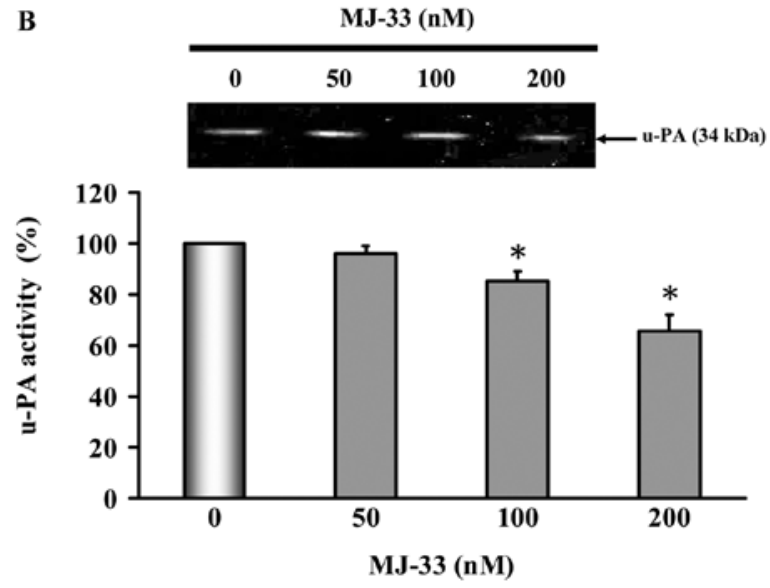

Figure 4. MJ-33 inhibited the activities of MMP-2, MMP-9 and u-PA of DU145 cells. Cells were treated with various concentrations $(0,50,100$ and $200 \mathrm{nM}$ ) of MJ-33 for $24 \mathrm{~h}$. The conditioned media were collected, and MMP-2, MMP-9 (Panel A) and u-PA activities (Panel B) were determined by gelatin or casein zymography. MMP-2 and u-PA activities were quantified by densitomeric analysis. The densitomeric data are expressed as the mean $\pm \mathrm{SD}$ of three independent experiments. " $\mathrm{p}<0.05$ indicates a significant difference compared to the control.

MJ-33 inhibits the MAPKs and AKT signaling pathways in DU145 cells. We investigated the effects of MJ-33 on metastatic protein levels in DU145 cells by western blotting. As shown in Fig. 5A, we determined DU145 cells after exposure to MJ-33 $(0,50,100$ and $200 \mathrm{nM})$ for $24 \mathrm{~h}$. MJ-33 reduced the protein levels of MMP-2, MMP-9 and u-PA. To clarify the possible upstream signaling pathways in MJ-33-treated DU145 cells, we evaluated the related protein levels in the MAPK (JNK, p38 and ERK) and AKT signaling pathways by western blotting. We determined DU145 cells after exposure to MJ-33 (0, 50, 100 and $200 \mathrm{nM}$ ) for $6 \mathrm{~h}$. We found that incubation of cells with MJ-33 reduced the protein levels of p-JNK, p-ERK, p-p38 and $\mathrm{p}-\mathrm{AKT}$.

$M J-33$ inhibits the AP-1 and $N F-\kappa B$ signaling pathways in DU145 cells. Numerous studies have reported that MMP-9, MMP-2 and u-PA promoters have several transcription binding motifs such as NF- $\mathrm{KB}$ and AP-1. In order to clarify the involvement of NF- $\kappa$ B and AP-1 proteins in the mechanisms of MJ-33's action, we evaluated the related protein levels in NF- $\kappa \mathrm{B}, \mathrm{c}-$ fos 
A

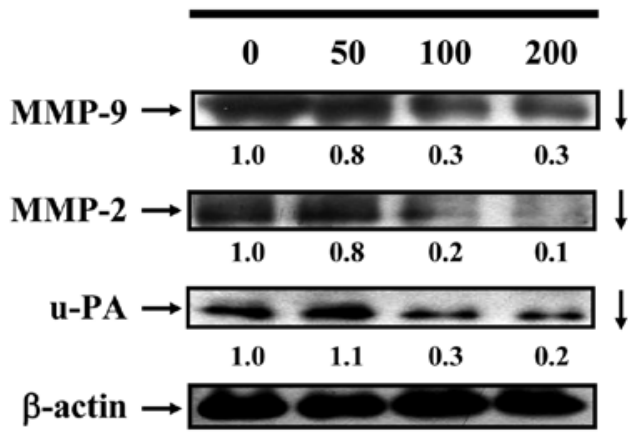

B

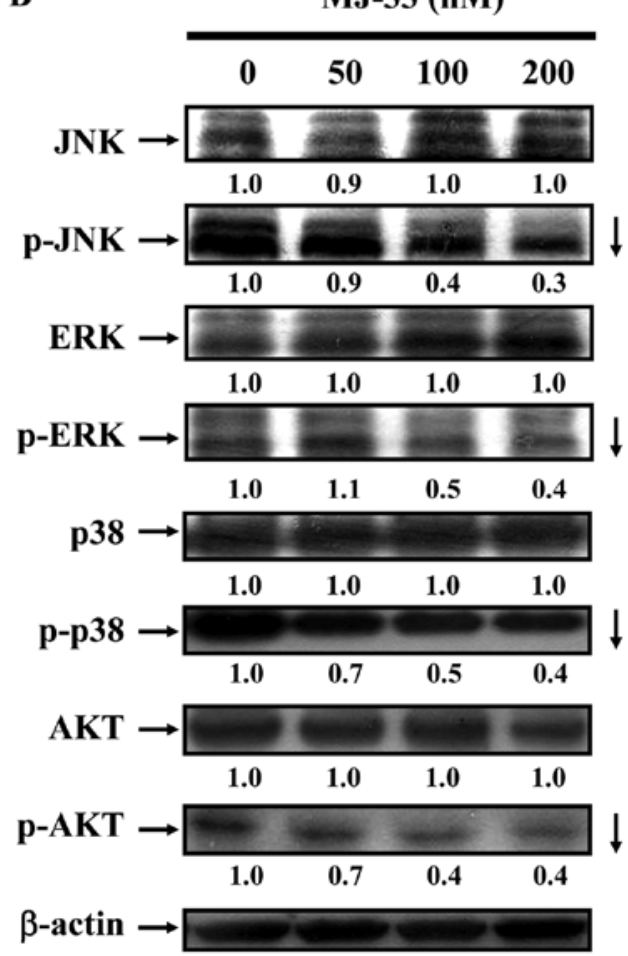

Figure 5. MJ-33 affects the levels of associated proteins in metastasis of DU145 cells in vitro. Cells were placed onto the plates with or without various concentrations of MJ-33 (0, 50, 100 and $200 \mathrm{nM})$ treatment for $24 \mathrm{~h}$ and were then isolated from each sample. The total and nuclear proteins were then prepared and were detected by western blotting as described in Materials and methods. The levels of (A) MMP-2, MMP-9, u-PA, and (B) p-JNK, p-ERK, p-p38, p-AKT expressions were examined by western blotting.

and c-Jun by western blotting. In addition, the effects of MJ-33 on DNA binding of NF- $\mathrm{NB}$ and AP-1 were determined using EMSA. We determined DU145 cells after exposure to MJ-33 (0, 50,100 and $200 \mathrm{nM}$ ) for $6 \mathrm{~h}$. We found that incubation of cells with MJ-33 reduced protein levels of NF- $\kappa \mathrm{B}$, c-fos and c-Jun. The results shown in Fig. 6B demonstrate that MJ-33 inhibited $\mathrm{NF}-\kappa \mathrm{B}$ and AP-1 DNA binding in a dose-dependent manner. Binding of NF- $\kappa \mathrm{B}$ and AP-1 were particularly inhibited by treatment with 100 and $200 \mathrm{nM}$ of MJ-33. Therefore, our study proposes that MJ-33 might block the invasion, migration and adhesion in DU145 cells by inhibiting AKT and MAPKs as well as suppressing the $\mathrm{NF}-\kappa \mathrm{B}$ signaling.

\section{Discussion}

Previous reports have found that quinazoline derivatives exert antitumor activity against seven types of cancer cells both in vitro and in vivo (18), and also induce apoptosis and inhibit metastasis in the U-2 OS human osterogenic sarcoma cell line (19). There is, however, no information on the effects of MJ-33 on invasion, migration and adhesion in human prostate cancer cells. Initially, three human prostate cancer cell lines (DU145, LNCaP and PC-3) were examined and it was observed that MJ-33 reduced DU145 cell viability more compared with the other two cell lines. Based on these findings, DU145 cells were used to examine the effects of MJ-33 on invasion, migration and adhesion. We found that MJ-33 can induce growth inhibition effects and inhibit invasion, migration and adhesion of DU145 cells (Fig. 3). Furthermore, these effects were associated with inactivation of the MAPKs (ERK, JNK, p38) and AKT (Fig. 5), inhibitory effects on $\mathrm{NF}-\kappa \mathrm{B}$, c-fos, and c-Jun transcriptional factors (Fig. 6). This effect on AP-1 and NF- $\kappa$ B transcription factors was consistent with less DNA binding of NF- $\kappa$ B and AP-1 DNA (Fig. 6B). MAPKs are intricately involved in the expression of the components involved in MMPs or u-PA promoter induction through NF- $\mathrm{BB}, \mathrm{AP}-1$ and its association with c-fos and c-Jun (20). Numerous studies from different cell types have suggested the MAPKs play a central role in regulating the activities of MMPs or U-PA (21-23). Inhibition of the MAPKs pathway might have the potential of preventing angiogenesis, proliferation, invasion, and migration occurring with a wide range of tumors.

Our findings reinforce the potential of MJ-33 as a new strategy for antitumor therapy, especially in the inhibition of cancer metastasis which is a major cause of mortality in cancer patients. MMP-2 and u-PA promoters have several transcription factor binding motifs, including NF- $\kappa$ B and AP-1 (24). Thus, multiple pathways leading to activation of $N F-\kappa B$ and AP-1 binding factors in tumor cells may contribute to MMP-2, MMP-9 and u-PA transcription and metastatic enhancement. We found that MJ-33 inhibited cell invasion, migration and adhesion through the downregulation of MMP-2 and MMP-9 protein abundance in DU145 cells. This is in agreement with our previous study that LJJ-10 (a novel quinazoline derivative) inhibited the invasion of human osteosarcoma U-2 OS cells through inhibition of MMP-2 and MMP-9. There is evidence that growth factors and cytokines affect MMP-9 expression through acting on the transcription factors $\mathrm{NF}-\kappa \mathrm{B}$ and AP-1 through the Ras/MAPK and PI3K/AKT signaling pathways (25). NF- $\kappa \mathrm{B}$ and AP-1 binding to the MMP-2 and MMP-9 promoter are centrally involved in the induction of $M M P-2$ and MMP-9 gene expression associated with tumor cell invasion (26-28). To further explore how MJ-33 inhibits invasion, migration and adhesion, we used gelatin or caseinplasminogen zymographic assays to detect activities of MMP-2, MMP-9, and u-PA. In this study, MJ-33 significantly decreased the levels of MMP-2, MMP-9 and u-PA activity (Fig. 4). These results indicate that the anti-metastatic effect of MJ-33 is associated with the inhibition of enzymatically degradative processes of tumor metastasis. Furthermore, we used a wound-healing and a Boyden chamber assay to quantify the migratory potential of DU145 cells. 
A

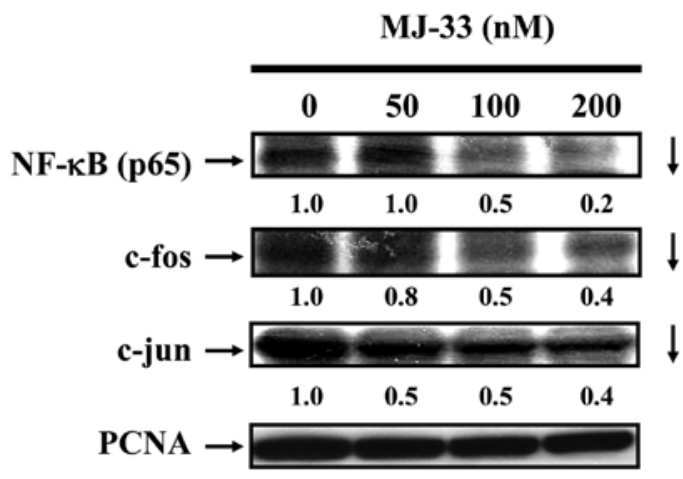

B

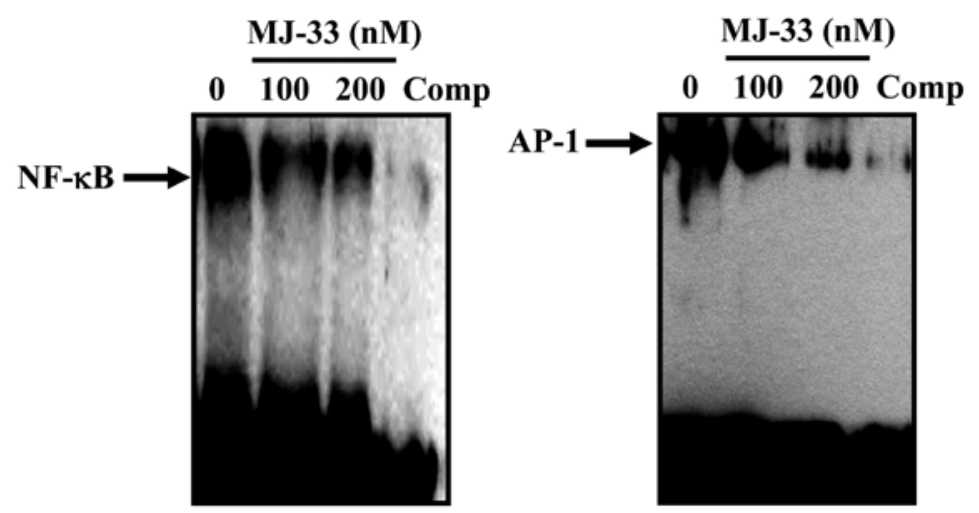

Comp: unlabeled consensus oligonucleotide

Figure 6. MJ-33 affects the DNA binding activities of NF- $\mathrm{kB}$ and AP-1 in DU145 cells. (A) NF- $\mathrm{\kappa B}$, c-fos and c-Jun expressions were examined by western blotting. (B) Cells were treated with 0,100 and $200 \mathrm{nM}$ of MJ-33 for $24 \mathrm{~h}$, and then nuclear extracts were prepared and analyzed for NF- $\mathrm{kB}$ and AP-1 DNA binding activity using biotin labeled consensus NF- $\mathrm{KB}$ and AP-1 specific oligonucleotides, and then EMSA assay was performed as described in Materials and methods. Lane 1, control; lane 2, $100 \mathrm{nM} \mathrm{MJ-33;} \mathrm{lane} \mathrm{3,} 200 \mathrm{nM} \mathrm{MJ}-33$; lane 4, unlabeled consensus oligonucleotides. Excess free probe is indicated at the bottom. Results from three repeated and separate experiments were similar.

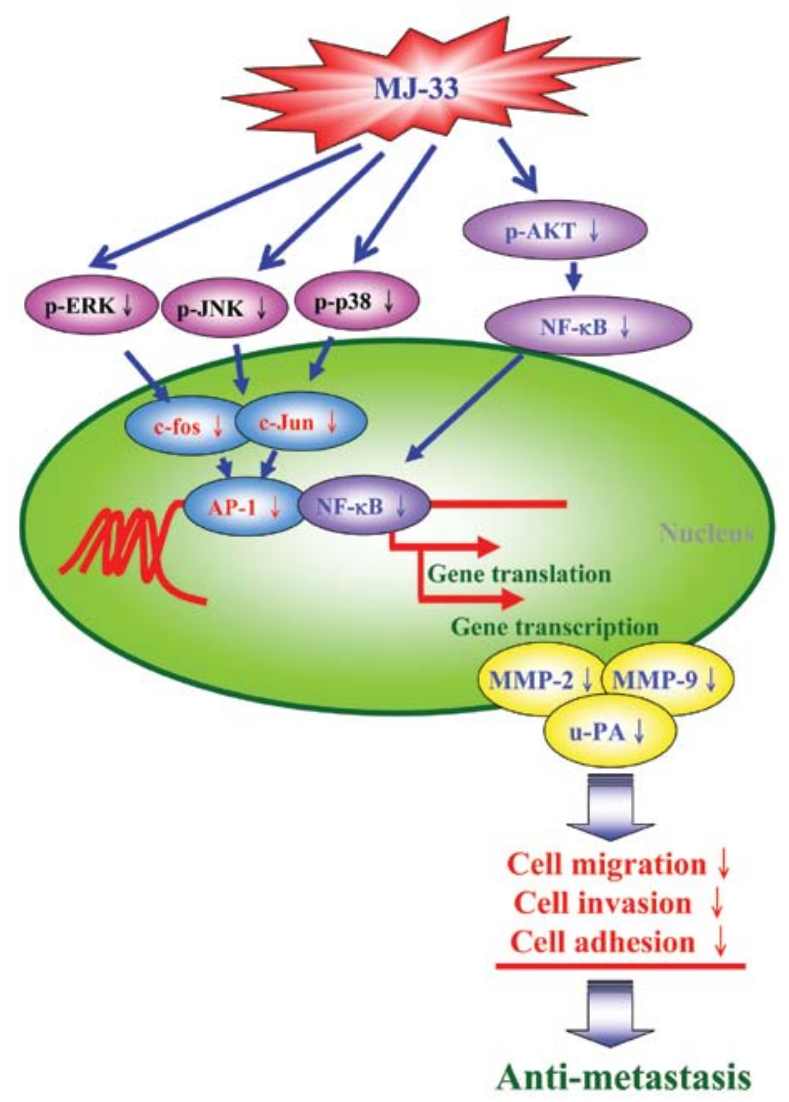

Figure 7. The proposed signaling pathways of MJ-33-inhibited invasion and migration in DU145 human prostate cancer cells.

Taken together, these observations suggest that MJ-33 significantly inhibits the invasion, migration and adhesion of DU145 cells. MJ-33 acts as an anti-metastatic agent in prostate cancer cells. Collectively, we have outlined the overall possible signaling pathways for MJ-33-inhibited metastasis in DU145 cells (Fig. 7). We explored for the first time and investigated the roles of AP-1 and NF- $\mathrm{KB}$ in reducing the levels and activities of MMP-2, MMP-9 and u-PA in human prostate cancer cells.

\section{Acknowledgements}

This study was supported by a research grant from the National Science Council of the Republic of China (NSC 101-2313-B039-008). We also thank Chi-Cheng Lu, Wen-Wen Huang and Shu-Fen Peng (Department of Biological Science and Technology, China Medical University) for their helpful suggestions and technical support. 


\section{References}

1. Jemal A, Siegel R, Ward E, Murray T, Xu J and Thun MJ: Cancer statistics, 2007. CA Cancer J Clin 57: 43-66, 2007.

2. Petrylak DP: The current role of chemotherapy in metastatic hormone-refractory prostate cancer. Urology 65: 3-8, 2005.

3. Chandrika PM, Yakaiah T, Rao AR, et al: Synthesis of novel 4,6-disubstituted quinazoline derivatives, their anti-inflammatory and anti-cancer activity (cytotoxic) against U937 leukemia cell lines. Eur J Med Chem 43: 846-852, 2008.

4. Chen Z, Huang X, Yang H, et al: Anti-tumor effects of B-2, a novel 2,3-disubstituted 8-arylamino-3H-imidazo[4,5-g]quinazoline derivative, on the human lung adenocarcinoma A549 cell line in vitro and in vivo. Chem Biol Interact 189: 90-99, 2011.

5. Yang JS, Hour MJ, Huang WW, Lin KL, Kuo SC and Chung JG: MJ-29 inhibits tubulin polymerization, induces mitotic arrest, and triggers apoptosis via cyclin-dependent kinase 1-mediated Bcl-2 phosphorylation in human leukemia U937 cells. J Pharmacol Exp Ther 334: 477-488, 2010.

6. Chen KT, Hour MJ, Tsai SC, et al: The novel synthesized 6-fluoro-(3-fluorophenyl)-4-(3-methoxyanilino)quinazoline (LJJ-10) compound exhibits anti-metastatic effects in human osteosarcoma U-2 OS cells through targeting insulin-like growth factor-I receptor. Int J Oncol 39: 611-619, 2011.

7. Liu KC, Huang AC, Wu PP, et al: Gallic acid suppresses the migration and invasion of PC-3 human prostate cancer cells via inhibition of matrix metalloproteinase-2 and -9 signaling pathways. Oncol Rep 26: 177-184, 2011.

8. Ma CY, Ji WT, Chueh FS, et al: Butein inhibits the migration and invasion of SK-HEP-1 human hepatocarcinoma cells through suppressing the ERK, JNK, p38, and uPA signaling multiple pathways. J Agric Food Chem 59: 9032-9038, 2011.

9. Lan $\mathrm{YH}, \mathrm{Wu} \mathrm{YC,} \mathrm{Wu} \mathrm{KW,} \mathrm{et} \mathrm{al:} \mathrm{Death} \mathrm{receptor} \mathrm{5-mediated}$ TNFR family signaling pathways modulate gamma-humuleneinduced apoptosis in human colorectal cancer HT29 cells. Oncol Rep 25: 419-424, 2011.

10. Huang WW, Ko SW, Tsai HY, et al: Cantharidin induces G2/M phase arrest and apoptosis in human colorectal cancer colo 205 cells through inhibition of CDK1 activity and caspase-dependent signaling pathways. Int J Oncol 38: 1067-1073, 2011.

11. Yu FS, Yang JS, Yu CS, et al: Safrole induces apoptosis in human oral cancer HSC-3 cells. J Dent Res 90: 168-174, 2011.

12. Lu CC, Yang JS, Huang AC, et al: Chrysophanol induces necrosis through the production of ROS and alteration of ATP levels in J5 human liver cancer cells. Mol Nutr Food Res 54: 967-976, 2010

13. Chiang JH, Yang JS, Ma CY, et al: Danthron, an anthraquinone derivative, induces DNA damage and caspase cascades-mediated apoptosis in SNU-1 human gastric cancer cells through mitochondrial permeability transition pores and Bax-triggered pathways. Chem Res Toxicol 24: 20-29, 2011.

14. Huang WW, Chiu YJ, Fan MJ, et al: Kaempferol induced apoptosis via endoplasmic reticulum stress and mitochondriadependent pathway in human osteosarcoma U-2 OS cells. Mol Nutr Food Res 54: 1585-1595, 2010.

15. Danthron. Rep Carcinog 12: 128-129, 2011.
16. Lo C, Lai TY, Yang JS, et al: Gallic acid inhibits the migration and invasion of A375.S2 human melanoma cells through the inhibition of matrix metalloproteinase- 2 and Ras. Melanoma Res 21: 267-273, 2011.

17. Kuo TC, Yang JS, Lin MW, et al: Emodin has cytotoxic and protective effects in rat C6 glioma cells: roles of Mdrla and nuclear factor kappaB in cell survival. J Pharmacol Exp Ther 330: 736-744, 2009.

18. Wang SW, Pan SL, Huang YC, et al: CHM-1, a novel synthetic quinolone with potent and selective antimitotic antitumor activity against human hepatocellular carcinoma in vitro and in vivo. Mol Cancer Ther 7: 350-360, 2008.

19. Hsu SC, Yang JS, Kuo CL, et al: Novel quinolone CHM-1 induces apoptosis and inhibits metastasis in a human osterogenic sarcoma cell line. J Orthop Res 12: 1637-1644, 2009.

20. Gondi CS and Rao JS: Therapeutic potential of siRNA-mediated targeting of urokinase plasminogen activator, its receptor, and matrix metalloproteinases. Methods Mol Biol 487: 267-281, 2009.

21. Chen PN, Hsieh YS, Chiou HL and Chu SC: Silibinin inhibits cell invasion through inactivation of both PI3K-Akt and MAPK signaling pathways. Chem Biol Interact 156: 141-150, 2005.

22. Westermarck J and Kahari VM: Regulation of matrix metalloproteinase expression in tumor invasion. FASEB J 13: 781-792, 1999.

23. Aguirre Ghiso JA, Alonso DF, Farias EF, Gomez DE and de Kier Joffe EB: Deregulation of the signaling pathways controlling urokinase production. Its relationship with the invasive phenotype. Eur J Biochem 263: 295-304, 1999.

24. Peng PL, Hsieh YS, Wang CJ, Hsu JL and Chou FP: Inhibitory effect of berberine on the invasion of human lung cancer cells via decreased productions of urokinase-plasminogen activator and matrix metalloproteinase-2. Toxicol Appl Pharmacol 214: 8-15, 2006.

25. Deryugina EI and Quigley JP: Matrix metalloproteinases and tumor metastasis. Cancer Metastasis Rev 25: 9-34, 2006.

26. Lin YT, Yang JS, Lin HJ, et al: Baicalein induces apoptosis in SCC-4 human tongue cancer cells via a $\mathrm{Ca}^{2+}$-dependent mitochondrial pathway. In Vivo 21: 1053-1058, 2007.

27. Chuang JY, Huang YF, Lu HF, et al: Coumarin induces cell cycle arrest and apoptosis in human cervical cancer HeLa cells through a mitochondria- and caspase- 3 dependent mechanism and NF-kappaB down-regulation. In Vivo 21: 1003-1009, 2007.

28. Huang YT, Hwang JJ, Lee LT, et al: Inhibitory effects of a luteinizing hormone-releasing hormone agonist on basal and epidermal growth factor-induced cell proliferation and metastasis-associated properties in human epidermoid carcinoma A431 cells. Int J Cancer 99: 505-513, 2002. 